\title{
Record of Haplotaxis aedeochaeta Brinkhurst \& Marchese, 1987 (Oligochaeta: Haplotaxidae) in a conservation unity in the state of São Paulo
}

\author{
N. A. O. Sanches*a (D), D. A. Girollia (D), G. R. Gornia (D), L. H. Sahm ${ }^{a}$ (D), \\ V. C. Colombo-Corbi ${ }^{a}$ (D) and J. J. Corbi ${ }^{b}$
}

aPrograma de Pós-graduação em Desenvolvimento Territorial e Meio Ambiente, Universidade de Araraquara - UNIARA, Rua Carlos Gomes, 1338, Centro, CEP 14801-340, Araraquara, SP, Brasil

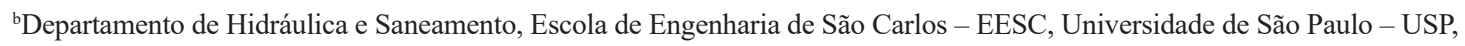
CP 359, CEP 13566-590, São Carlos, SP, Brasil

*e-mail: nathalie_sanches@hotmail.com

Received: June 12, 2019 - Accepted: September 10, 2019 - Distributed: February 28, 2021 (With 1 figure)

Oligochaeta is a diversified, widely distributed group that inhabits terrestrial, marine and freshwater environments (Timm, 2017). In continental aquatic ecosystems, it is composed of more than 1.100 known species (Martin et al., 2008), which play an important role in the decomposition process as most species are detritivorous (Rodriguez and Reynoldson, 2011). These organisms can be found in several microhabitats in aquatic environments, living in sediment or in water columns (Rodriguez and Reynoldson, 2011) and in association with other organisms (Corbi et al., 2004, 2005; Gorni and Alves, 2007; Martins and Alves, 2008; Oda et al., 2015). In addition, they have limited mobility and are influenced by habitat characteristics (Behrend et al., 2012), which make them efficient bioindicators of water quality.

However, despite the growing number of research projects focused on oligofauna in Brazil (Rosa et al., 2015; Sanches et al., 2016; Takeda et al., 2017), few regions have an inventory, thus explaining the need to intensify research throughout the country. In this scenario, the Southeast and South regions, represented mainly by the states of São Paulo, Minas Gerais and Paraná, are among those with the greatest amount of research performed (Rodrigues and Alves, 2018).

In this note, we report the record of the species Haplotaxis aedeochaeta in aquatic systems in a conservation unity in the state of São Paulo. The samples were collected in Ribeirão Bonito river at "Morro do Diabo" State Park in 2015 (22³0'12" S and 52²1'30" W) by the Environmental Company of the state of São Paulo (CETESB) following methodological procedures of the Technical Standard CETESB L5.309 (CETESB, 2003). We used the taxonomic criteria adopted by Brinkurst and Marchese (1989) in the oligochaetes identification. According to Brinkurst and Marchese $(1987,1989)$, this species is characterized as being long and thin, similar to a line and by a ventral chaetae single, longer and nodulate with curved distal end (Figure 1). The dorsal chaetae, when present, is short and
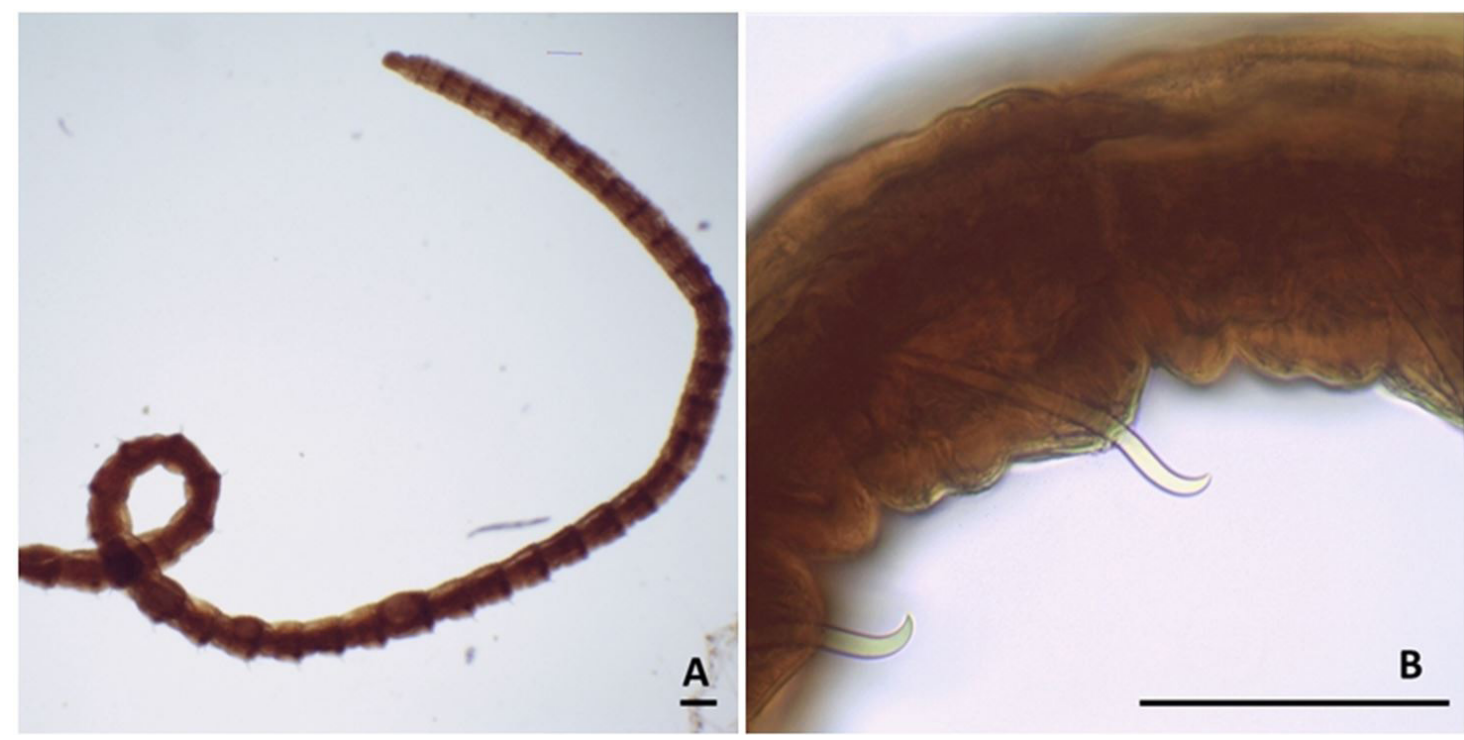

Figure 1. Haplotaxis aedeochaeta - A: Specimen overview (long and thin) and B: solitary chaetae with curved distal end. Scale bars: $100 \mu \mathrm{m}$. 
straight. The prostomium is large and divided by a groove, but without proboscis. The genital chaetae is large, similar to a capillary and occurs in segment XII.

In Brazil, Haplotaxis aedeochaeta had registered occurrence in the state of Paraná (Behrend et al., 2009; Montanholi-Martins and Takeda 1999, 2001; Petsch et al., 2015; Ragonha and Takeda, 2014; Ragonha et al.. 2014), mainly in the Paraná River and its tributaries. Recently, it was evidenced in the state of Mato Grosso by Gorni et al. (2018) on Juruena River and Mato Grosso do Sul by Takeda et al. (2017) in the Ivinhema River region. In São Paulo, the species has already been collected by Oliveira (2009) on the Araquá River in the municipality of Botucatu in an area with few riparian forest and great influence of agribusiness. In other countries of South America, it occurs only in Argentina (Christoffersen, 2007).

The present research increases the data on the occurrence of $H$. aedeochaeta. This fact shows the importance of elaborating inventories for Brazilian aquatic ecosystems in order to reduce the gaps in data on neotropical biodiversity and highlight the importance of these organisms to the scientific community, also making possible their use in environmental monitoring research as bioindicators.

\section{Acknowledgements}

The authors are grateful to the Water Communities Sector (ELHC) of the Environmental Company of the state of São Paulo - CETESB, especially to the biologists Monica Luisa Kuhlmann and Hélio Rubens Victorino Imbimbo. The Coordination of Improvement of Higher Education Personnel (CAPES) for financial support.

\section{REFERENCES}

BEHREND, R.D.L., FERNANDES, S.E.P., FUJITA, D.S. and TAKEDA, A.M., 2009. Eight years of monitoring aquatic Oligochaeta from the Baía and Ivinhema Rivers. Brazilian Journal of Biology = Revista Brasileira de Biologia, vol. 69, no. 2, suppl., pp. 559-571. http://dx.doi.org/10.1590/S1519-69842009000300011. PMid:19738963.

BEHREND, R.D.L., TAKEDA, A.M., GOMES, L.C. and FERNANDES, S.E.P., 2012. Using oligochaeta assemblages as an indicator of environmental changes. Brazilian Journal of Biology $=$ Revista Brasileira de Biologia, vol. 72, no. 4, pp. 873-884. http://dx.doi.org/10.1590/S1519-69842012000500014. PMid:23295517.

BRINKHURST, R.O. and MARCHESE, M., 1987. A contribution to the taxonomy of the aquatic Oligochaeta (Haplotaxidae, Phreodrilidae, Tubificidae) of South America. Canadian Journal of Zoology, vol. 65, no. 12, pp. 3154-3165. http://dx.doi. org/10.1139/z87-474.

BRINKURST, R.O. and MARCHESE, M.R., 1989. Guia para la identificación de oligoquetos acuáticos continentales de Sud y Centroamerica. Santa Fé: Asociación de ciencias naturales del litoral, $207 \mathrm{p}$.

CHRISTOFFERSEN, M.L., 2007. A catalogue of aquatic microdrile oligochaetes (Annelida: Clitellata) from South America. Shui Sheng Sheng Wu Hsueh Bao, vol. 31, no. 1, pp. 59-86.
COMPANHIA AMBIENTAL DO ESTADO DE SÃO PAULO - CETESB, 2003 [viewed 27 January 2019]. CETESB L5.309: determinação de bentos de água doce: macroinvertebrados: métodos qualitativo e quantitativo [online]. São Paulo: CETESB, 16 p. Available from: http://cetesb.sp.gov.br/normas-tecnicascetesb/normas-tecnicas-vigentes/

CORBI, J.J., JANCSO, M.A., STRIXINO, S.T. and FRAGOSO, E.N., 2004. Occurence of oligochaeta living on larvae of odonata from Ipeúna (São Paulo State, Brazil). Biota Neotropica, vol. 4, no. 2, pp. 1-3. http://dx.doi.org/10.1590/S1676-06032004000200017.

CORBI, J.J., ROQUE, F.O., TRIVINHO-STRIXINO, S. and ALVES, R.G., 2005. Records of oligochaetes in freshwater sponges, on bryozoans, and on colonial hydrozoans from Brazil. Brazilian Journal of Biology $=$ Revista Brasileira de Biologia, vol. 65, no. 1, pp. 1-2. http://dx.doi.org/10.1590/S1519-69842005000100022. PMid:16025917.

GORNI, G.R. and ALVES, R.D.G., 2007. Naididae (Annelida, Oligochaeta) associated with briophytes in Brotas, State of São Paulo, Brazil. Revista Brasileira de Zoologia, vol. 24, no. 2, pp. 518-519. http://dx.doi.org/10.1590/S0101-81752007000200036.

GORNI, G.R., SANCHES, N.A.D.O., COLOMBO-CORBI, V. and CORBI, J.J., 2018. Oligochaeta (Annelida: Clitellata) in the Juruena River, MT, Brazil: species indicators of substrate types. Biota Neotropica, vol. 18, no. 4, pp. 1-9. http://dx.doi. org/10.1590/1676-0611-bn-2018-0566.

MARTIN, P., MARTINEZ-ANSEMIL, E., PINDER, A., TIMM, T. and WETZEL, M.J., 2008. Global diversity of Oligochaetous clitellates ("Oligochaeta"; Clitellata) in freshwater. Hydrobiologia, vol. 595, no. 1, pp. 117-127. http://dx.doi.org/10.1007/s10750007-9009-1.

MARTINS, R.T. and ALVES, R.D.G., 2008. Occurrence of Naididae (Annelida: Oligochaeta) from three gastropod species in irrigation fields in southeastern Brazil. Biota Neotropica, vol. 8, no. 3, pp. 256-257. http://dx.doi.org/10.1590/S167606032008000300023 .

MONTANHOLI-MARTINS, M.C. and TAKEDA, A.M., 1999. Communities of benthic oligochaetes in relation to sediment structure in the Upper Paraná River, Brazil. Studies on Neotropical Fauna and Environment, vol. 34, no. 3, pp. 52-58. http://dx.doi. org/10.1076/snfe.34.3.52.8899.

MONTANHOLI-MARTINS, M.C. and TAKEDA, A.M., 2001. Spatial and temporal variations of oligochaetes of the Ivinhema River and Patos Lake in the Upper Paraná River Basin, Brazil. Hydrobiologia, vol. 463, no. 1-3, pp. 197-205. http://dx.doi. org/10.1023/A:1013163927814.

ODA, F.H., PETSCH, D.K., RAGONHA, F.H., BATISTA, V.G., TAKEDA, A.M. and TAKEMOTO, R.M., 2015. Dero (Allodero) lutzi Michaelsen, 1926 (Oligochaeta: Naididae) associated with Scinax fuscovarius (Lutz, 1925)(Anura: Hylidae) from Semideciduous Atlantic Rain Forest, southern Brazil. Brazilian Journal of Biology = Revista Brasileira de Biologia, vol. 75, no. 1, pp. 8690. http://dx.doi.org/10.1590/1519-6984.07613. PMid:25945624.

OLIVEIRA, P.C.D.R., 2009. Comunidade de macroinvertebrados bentônicos e qualidade da água e do sedimento das bacias hidrográficas dos Rios Lavapés, Capivara, Araquá e Pardo, Município de Botucatu $(S P)$ e região. São Paulo: Universidade Estadual Paulista, 184 p. Dissertação de mestrado em Ciencias Biológicas.

PETSCH, D.K., RAGONHA, F.H., GIMENEZ, B.C.G., BARBOZA, L.G.A. and TAKEDA, A.M., 2015. Partitioning beta diversity of aquatic Oligochaeta in different environments 
of a Neotropical floodplain. Acta Scientiarum Health Sciences, vol. 37, no. 1, pp. 41-49.

RAGONHA, F.H. and TAKEDA, A.M., 2014. Does richness of Oligochaeta (Annelida) follows a linear distribution with habitat structural heterogenety in aquatic sediments? Journal of Limnology, vol. 73, no. 1, pp. 146-156. http://dx.doi.org/10.4081/ jlimnol.2014.791.

RAGONHA, F.H., PETSCH, D.K., ALVES, G.H.Z., SANTANA, H.S., MICHELAN, T.S. and TAKEDA, A.M., 2014. Tributaries as richness source for Oligochaeta assemblage (Annelida) of Neotropical dammed river. Brazilian Journal of Biology $=$ Revista Brasileira de Biologia, vol. 74, no. 4, pp. 861-869. http://dx.doi. org/10.1590/1519-6984.05613. PMid:25627596.

RODRIGUES, L.F.T. and ALVES, R.G., 2018. Global panorama of studies about freshwater oligochaetes: main trends and gaps. Papéis Avulsos de Zoologia, vol. 58, no. 1, pp. 1-6. http://dx.doi. org/10.11606/1807-0205/2018.58.38.

RODRIGUEZ, P. and REYNOLDSON, T.B., 2011. The pollution biology of aquatic oligochaetes. Heidelberg: Springer Science \& Business Media. http://dx.doi.org/10.1007/97894-007-1718-3.
ROSA, B.F.J.V., MARTINS, R.T. and ALVES, R.G., 2015. Distribution of oligochaetes in a stream in the Atlantic Forest in southeastern Brazil. Brazilian Journal of Biology $=$ Revista Brasileira de Biologia, vol. 75, no. 1, pp. 1-7. http://dx.doi. org/10.1590/1519-6984.02313. PMid:25945614.

SANCHES, N.A.O., SAHM, L.H., GOMES, D.F., CORBI, J.J., RIBEIRO, M.L. and GORNI, G.R., 2016. Inventário de Oligochaeta (Annelida:Clitellata) em córregos urbanos de BocainaSP, Brasil. ReBraM, vol. 19, no. 1, pp. 14-24.

TAKEDA, A.M., TAKEDA, A.M., FUJITA, D.S., RAGONHA, F.H., PETSCH, D.K. and MONTANHOLI-MARTINS, M.C., 2017. Oligochaeta (Annelida) de ambientes aquáticos continentais do Estado do Mato Grosso do Sul (Brasil). Iheringia. Série Zoologia, vol. 107, no. 1, suppl., pp. 1-5. http://dx.doi.org/10.1590/1678$4766 \mathrm{e} 2017107$.

TIMM, T., 2017. Aquatic microdrile Oligochaeta (Annelida, Clitellata): new nominal taxa and combinations since 1984. Zootaxa, vol. 4282, no. 3, pp. 401-452. http://dx.doi.org/10.11646/ zootaxa.4282.3.1. 